\title{
IMMEDIATE EFFECTS OF PRESCRIBED BURNING ON SOIL MITE (ACARI: ORIBATIDA) COMMUNITIES IN A SCOTS PINE (PINUS SYLVESTRIS) FOREST, LATVIA
}

\author{
Rebeka Šḳērstiṇa $^{1}$ and Uǵis Kagainis ${ }^{1,2, \#}$ \\ ${ }^{1}$ Faculty of Biology, University of Latvia, 1 Jelgavas Street, LV-1586, Rīga, LATVIA \\ 2 Institute of Biology, University of Latvia, 1 Jelgavas Street, LV-1586, Rīga, LATVIA \\ \# Corresponding author: ugis.kagainis@lu.Iv
}

Communicated by Viesturs Melecis

\begin{abstract}
Prescribed burning is used to maintain and restore habitats, to protect and increase species biodiversity. Knowledge about soil fauna is limited, especially on community responses to fire disturbances. The aim of this study was to determine the immediate effects of prescribed burning on soil armoured mite (Acari: Oribatida) communities, vegetation cover and soil physiochemical properties in a boreal Scots pine forest in Latvia. Soil samples were collected on the day of the prescribed burning in the protected landscape area "Ādaži" and 16 days after. No significant changes in abiotic factors were found. Fire significantly decreased the vegetation cover. After the burning, the total number of oribatid mites decreased by $93 \%$, and the number of species by $77 \%$. Changes in oribatid mite communities were significantly influenced by fire severity. The number of individuals decreased among all taxa, except Brachychthonioidea spp. and Cosmochthonius lanathus. A significant decrease in abundance was observed in previously abundant species - Suctobelbella spp., Oppiella nova and Tectocepheus velatus. After the burning, Suctobelbella spp. was an eudominant and Tectocepheus spp. was a dominant genus.
\end{abstract}

Key words: prescribed burning, mite abundance, immediate response, soil, fire severity, dominance structure.

\section{INTRODUCTION}

Armoured mites (Acari: Oribatida) are important decomposers of organic matter. These small-size arthropods are often characterised by high species diversity and population density (Dindal, 1990; Eisenbeis, 2006; Nardi, 2007; Krantz and Walter, 2009; Dhooria, 2016). Changes in their population structure and abundance are used as indicators of the intensity of various disturbances, even long after the disturbance events (Crossley et al., 1997; Kudryasheva and Laskova, 2002; Gongalsky et al., 2012). Nonetheless, Oribatida mites have been rarely used in succession research (Zaitsev and Straalen, 2001). Succession research is often difficult because of the high variability of environments, local conditions, limited possibilities of control sampling and sufficient number of replicate samples (Malmström, 2010; Zaitsev et al., 2016).

Forest fires have an important role in maintaining nutrient cycles, productivity and biological diversity in forests
(Parviainen, 1996; Walter and Proctor, 1999; Bengtsson et $a l ., 2000)$ and they are followed by a pyrogenous succession (Johnstone and Chapin, 2006; Murvanidze et al., 2008). Prescribed burning is used to maintain and restore several habitats, and to protect and increase species biodiversity (Rove, 2008; Pastro et al., 2011; Larroulet et al., 2016). In the past 100 years, large-scale forest fires in Latvia have become significantly rarer (Donis et al., 2017). Long-time periods between the burns mean that most organisms have not adapted to survive such events (Bengtsson, 2002). Burning is a highly heterogeneous process. The resulting changes depend on fire intensity, physical and chemical properties of the ecosystem, characteristics of fauna and flora (HenigSever et al., 2001), burning duration, weather conditions at the time of the burn and before it, etc. (Schimmel and Granström, 1996; Ryan, 2002; Kirby and Watkins, 2015). Soil is generally considered to be a rather stable environment (Stamou et al., 1993; Scheinost et al., 1997; Krantz and Walter, 2009), but fire causes many significant changes 
from vegetation cover to various soil properties (Certini, 2005; Parsons et al., 2010; Hansen et al., 2017). Some of the most often monitored soil properties are soil moisture (Lóšková et al., 2013; Saifutdinov et al., 2018; Auclerc et al., 2019), pH (Henig-Sever et al., 2001; Kim and Jung, 2008; Murvanidze et al., 2008) and organic carbon (Kim and Jung, 2008; Murvanidze et al., 2008; Auclerc, 2019; Olejniczak et al., 2019).

Fire causes a significant influence on armoured mite diversity and number of individuals (Kudryasheva and Laskova, 2002; Gongalsky et al., 2012; Kim and Jung, 2013). Most taxonomic groups of boreal forest soil microarthropods cannot survive temperatures higher than $36{ }^{\circ} \mathrm{C}$ for extended periods of time. In comparison, armoured mites can withstand higher temperatures. Scheloribates sp., Sheloribates sp. and Steganacarus sp. can resist temperatures higher than $40{ }^{\circ} \mathrm{C}$ (Malmström, 2008). It is important to understand how fire affects soil fauna and how the soil fauna can indicate the effects of the fire long after the disturbance. Knowledge of soil mite community responses to fire disturbance is limited and more field experiments are necessary to consider the influence of microhabitats, heterogeneity of the disturbance and mite migration in the soil (Liiri et al., 2002; Barrios, 2007; Hutchins et al., 2011; George et al., 2017; Kamczyc et al., 2017). The aim of this study was to determine the immediate effects of prescribed burning on soil armoured mite communities and their influencing factors - vegetation cover and soil parameters in a Scots pine forest.

\section{MATERIALS AND METHODS}

Study site. The study was conducted in a 95-year-old Scots pine Pinus sylvestris forest in the protected landscape area "Ādaži" (Fig. 1). Some of Europe's most threatened species and habitats have been registered in this territory and prescribed burning is used to protect and restore the habitats (Rove, 2008). Ground vegetation was mainly dominated by Vaccinium myrtillus and Vaccinium vitis-idea shrubs, Pteridium aquilinum ferns, Pleurozium schreberi and Hylocomium splendens mosses. Soil was sandy, nutrient poor, forming a relatively thin $(9-11 \mathrm{~cm})$ humus layer. Soil $\mathrm{pH}$ ranged from 2.7 to 3.8 .

Sampling and description of biotic and abiotic factors. Unburned samples (U) were collected one hour before the prescribed burn on 26 July 2017. (Fig. 2.A). The burning lasted for two hours (I. Mārdega, pers. comm.) (Fig. 2.B). Samples were collected on a 60-metre-long transect (middle point (coordination system LKS-92): N 523657.28, E 333755.12) in an east-west direction (Fig. 3). Burned (B) samples were collected 16 days after the burn (Fig. 2.C). Between the sampling times, the lowest air temperature was $+11.1{ }^{\circ} \mathrm{C}$ (8 August 2017), highest $+25.9^{\circ} \mathrm{C}$ (31 July 2017), and total precipitation was $23.4 \mathrm{~mm}$ (Latvian Environment, Geology, and Meteorology Centre).

The transect consisted of 20 sampling plots with size $1 \times 1$ $\mathrm{m}$, with distances $3 \mathrm{~m}$ apart. In the centre of each sampling

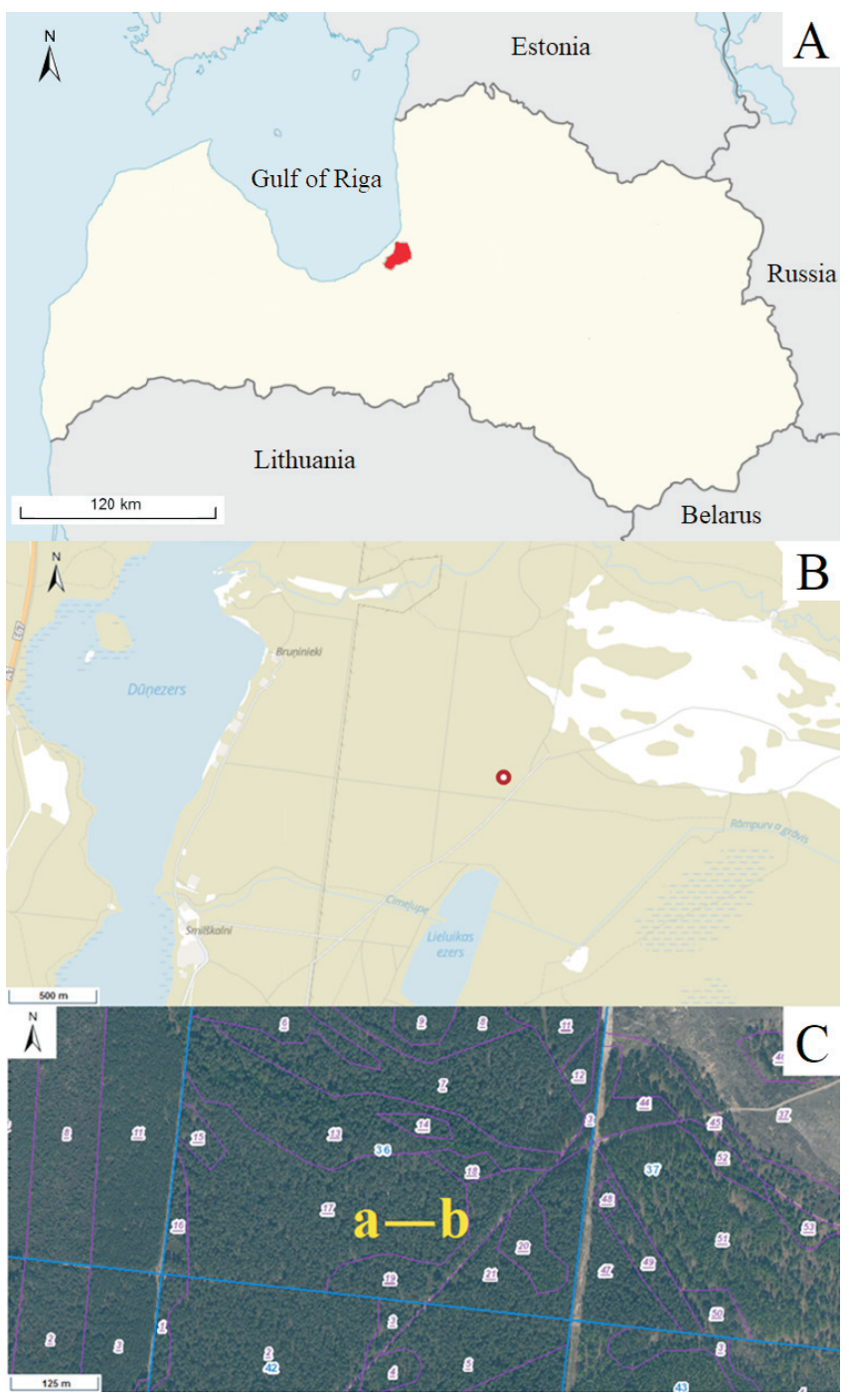

Fig. 1. A, Location of the protected landscape area "Ādaži" in Latvia (indicated with red). The sampling site in Ādaži military base. B, middle point of the transect ( $\odot$ ). Dūn,ezers - Lake Dūn,ezers. Lieluikas ezers - Lake Lieluikas; $\mathrm{C}-$ the location of the transect ( $)$ in the forest. a - west point of the transect, $\mathrm{b}$ - east point. With blue are indicated forestry section borders and numbers, with purple are indicated forestry plot borders and numbers (http://ozols.daba.gov.lv, modified).

plot, two soil samples were taken a distance of $10 \mathrm{~cm}$ from each other using different soil borers. One core (depth -15 $\mathrm{cm}$, area $-19.6 \mathrm{~cm}^{2}$ ) was collected for further analysis of the soil fauna, and for determination of thickness of the $\mathrm{O}$ horizon $(\mathrm{cm})$ and relative moisture $(\%)$. The other core (depth $-10 \mathrm{~cm}$, area $-100 \mathrm{~m}^{2}$ ) was taken for organic carbon and soil $\mathrm{pH}$ analysis. Soil samples were stored in closed plastic bags at $+4{ }^{\circ} \mathrm{C}$ temperature until further use for a maximum of two weeks.

Vegetation cover was described using the Braun-Blanquet method (Braun-Blanquet, 1964). Vaccinium spp. was not identified to the species level, because in most cases after the burn it was not possible to distinguish between $V$. myrtillus and $V$. vitis-idea. Sampling of burned soil was done 16 days after the burn. Each plot was moved $50 \mathrm{~cm}$ to the west of the transect in order to avoid disturbances that could be 

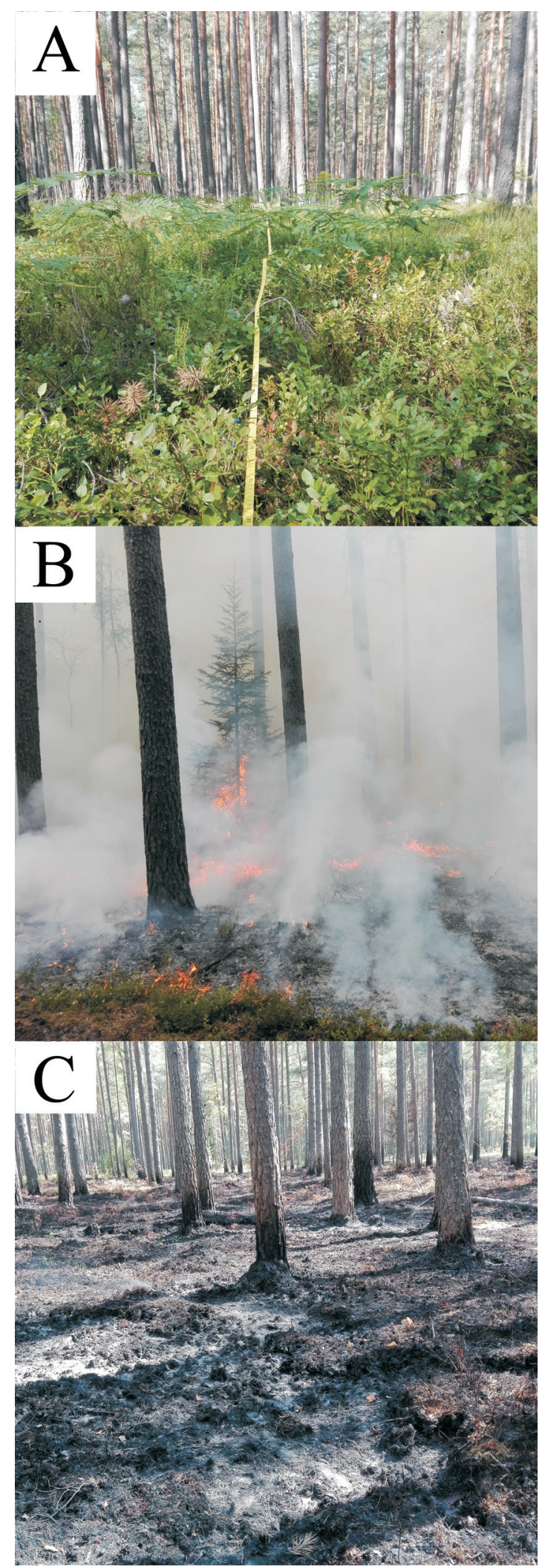

Fig. 2. The sampling site before (A), during the prescribed burning (B) and 16 days after (C).

caused by the previous sampling. All burnt samples were classified by burn severity according to Ryan (2002).

Soil oribatid mites and soil parameters. Soil invertebrates were extracted over a two-week period using Tullgren fun- nels equipped with $25 \mathrm{~W}$ light bulbs (Southwood and Henderson, 2000). The extracted oribatid mites were sorted and permanently mounted on microscopic slides using Berlese media (Krantz and Walter, 2009). Slides were kept in a thermostat oven Memmert GmbH 100-800 for two weeks at $+50{ }^{\circ} \mathrm{C}$ for hardening the media and achieving optically clearer observations under the light microscope (100-650x magnification) (Krantz and Walter, 2009). Identification was done using an identification key (Weigmann, 2006) and the IBULC specimen collection (Kagainis et al., 2020). This collection covers the largest part of the species recorded in the territory of Latvia. Species were identified by the second author and verified for a part of species by Dr. G. Weigmann (Germany), Dr. R. Penttinen (Finland) and Dr. M. Murvanidze (Georgia). The oribatid mite taxonomy follows the Weigmann (2006). The microscopic slides are deposited at the Department of Zoology and Animal Ecology, Faculty of Biology (University of Latvia).

Soil samples for physico-chemical analysis were air-dried at $18{ }^{\circ} \mathrm{C}$ for 24 hours. After drying, soil was sieved using a 2 $\mathrm{mm}$ mesh for $\mathrm{pH}$ analysis and a $0.25 \mathrm{~mm}$ mesh for analysis of organic carbon (\%). Soil $\mathrm{pH}$ was determined using $5 \mathrm{~g}$ of soil and $1 \mathrm{M}$ potassium chloride (Anonymous, 2005). Soil organic carbon (SOC) was determined using the Tyurin method (Tyurin, 1951) with three replications for each sample. Samples for mite analysis were weighed with an electronic scale Kern \& Sonh W600-2M ( $\pm 0.1 \mathrm{~g})$ before and after the fauna extraction to calculate the relative moisture of soil (Dunger and Fiedler, 1997).

Data analysis. Data were collected and sorted into chart sheets and the standard deviation was calculated using Microsoft Excel 2016. Wilcoxon test and box-whisker plots were used to compare soil parameters and vegetation cover with RStudio (version 3.3.2) software (Anonymous, 2019). ANOSIM was used to determine the difference between oribatid mite communities before and after the burn. ANOSIM analysis included the Bray-Curtis dissimilarity test conducted under 999 free permutations (Clarke and Warwick, 2001).

Shannon's index of diversity (H') was calculated for mite species data and Nonmetric Multidimensional Scaling (NMS) was used in order to compare Oribatida communities in PCORD 5 (McCune and Mefford, 1999). Sorensen (Bray-Curtis) distance as well as Slow and Thorough test and Autopilot and Monte Karlo (1000 runs) tests were executed (Lepš and Šmilauer, 2003). For conducting NMS, logarithmic transformation of mite species abundances was conducted (Kruskal, 1964). Spearman correlations of species and environmental factors with NMS ordination axis values were determined in RStudio. Correlation was interpreted in accordance with J. Fowler and others (Fowler et al., 1998). For data on Lycopodium annotinum and Trientalis europea cover, the test was not done due to the low number of individuals. Dominance structure was based on Engelmann (1978). Juvenile armoured mites were not included in the further analysis. 

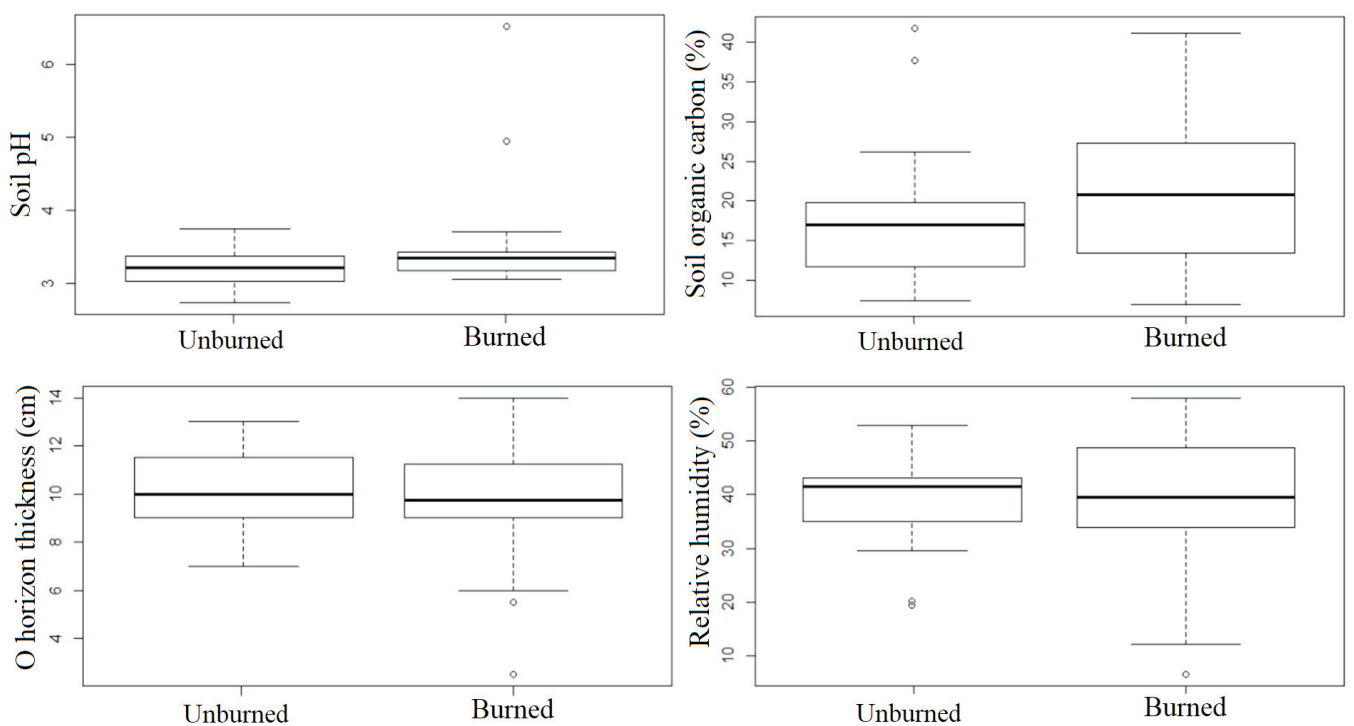

Fig. 3. Box-Whisker plots of various soil parameters in Ādaži sample plots before and after the prescribed fire.

\section{RESULTS}

Before the prescribed burning, the average relative soil moisture was $39.2 \%$, organic carbon - $18.12 \%$, thickness of the $\mathrm{O}$ horizon $-10.2 \mathrm{~cm}$ and total vegetation cover almost $100 \%$. Compared to the unburned samples after the immediate burn, no significant changes of these parameters were found (Wilcoxon test, $\alpha=0.05$ ), but all values showed an increase in standard deviation (Fig. 3, Table 1). Among all abiotic factors, the most significant changes of standard deviations were observed for soil $\mathrm{pH}$ (Table 1). Additionally, soil $\mathrm{pH}$ and the thickness of $\mathrm{O}$ horizon had extreme values among multiple samples after the fire disturbance. A significant change in the total vegetation cover $(p=0.003)$ was found. On average, fire disturbance decreased vegetation cover by $21 \%$ among the sampling plots.

In total, we recorded 1934 adult individuals representing 39 Oribatida species and morphospecies. Suctobelbella, Phthiracarus, part of genus Scheloribates and the superfamily Brachychthonioidea were not determined to the species level. Superfamily Oppioidea - Oppiella nova $(\mathrm{n}=706)$ and Suctobelbella spp. $(\mathrm{n}=645)$ represent the largest number of individuals (Table 2). A considerable number of individuals were identified as the species Tectocepheus velatus $(\mathrm{n}=199)$ and Microppia minus $(\mathrm{n}=78)$. Significant changes in diversity index and number of species per plot $(p<0.01)$ were associated with fire severity. Oribatid mite community showed statistically different composition after the immediate burn $(\mathrm{R}=0.39, p<0.01)$ (Fig. 4). After the burn, only $36 \%$ of the morphospecies were found. On average, the number of oribatid mite species decreased four times, and Shannons index by two times in burnt samples, compared to the unburned samples. The number of individuals decreased among all taxa, except for Brachychthonioidea spp. and Cosmochthonius lanathus (Table 2).

Oribatid mite species composition was significantly changed after the burning (Fig. 5). Suctobelbella spp. became eudominant from dominant, and Tectocepheus spp.,
Table 1. Wilcoxon test $p$ values among abiotic factors, their standard deviations (Sd) differences between $\mathrm{Sd}(\%)$

\begin{tabular}{l|c|c|c|c}
\hline \multirow{2}{*}{ Parameter } & \multirow{2}{*}{$p$} & \multicolumn{3}{c}{ Standard deviation (Sd) } \\
\cline { 3 - 5 } & & unburned & burned & $\begin{array}{c}\text { difference } \\
(\%)\end{array}$ \\
\hline Thickness of O horizon & 0.79 & 1.65 & 2.68 & 38 \\
Relative moisture of the soil & 0.70 & 8.71 & 12.60 & 31 \\
Soil organic carbon & 0.37 & 9.30 & 10.06 & 8 \\
Soil pH & 0.15 & 0.26 & 0.81 & 68
\end{tabular}

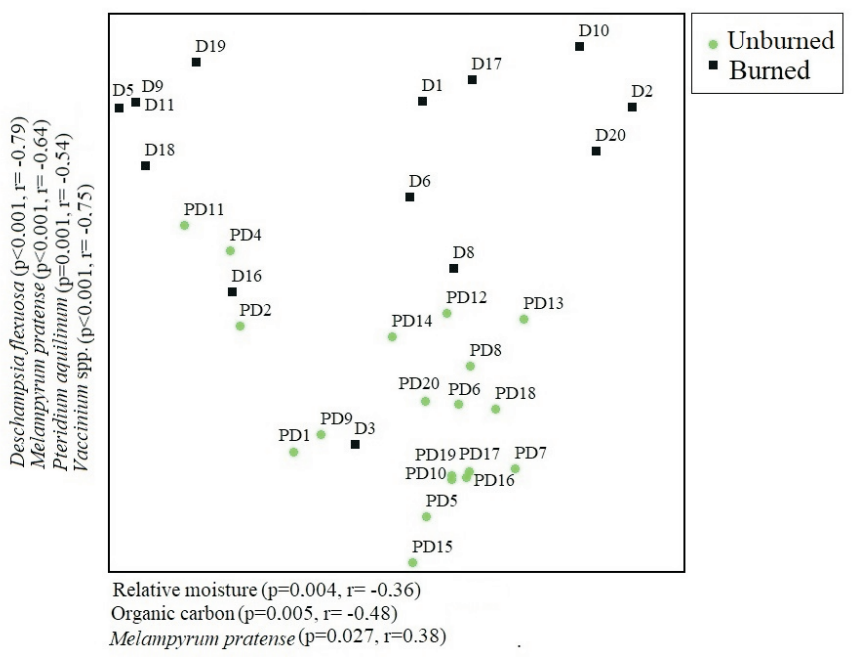

Fig. 4. NMS sample ordination of mite abundance matrix before and after fire in the territory of Ādaži, Latvia. Correlation of axes with with five plant taxa and abiotic factors are given.

which was a subdominant, became a dominant genus after the disturbance. Oppiella nova remained as a dominant species, while Microppia minus and S. carinatus were recedents in the unburned plot and became sub-recedents after the burn. In general, there were less recedent and subrecedent species (decrease by $3 \%$ and $4 \%$, respectively) after the burn. 
Table 2. Number of oribatid mites found in the study area

\begin{tabular}{|c|c|c|}
\hline Taxa & Unburned & Burned \\
\hline Brachychthoniodea spp. (Thor, 1934) & 1 & 1 \\
\hline Cosmothonius lanatus (Michael, 1885) & 2 & 5 \\
\hline Phthiracarus spp. (Petty, 1841) & 5 & 1 \\
\hline Steganacarus striculus (C.L. Koch, 1836) & 1 & 0 \\
\hline Steganacarus carinatus (C.L. Koch, 1841) & 49 & 1 \\
\hline Rhysotritia ardua (C.L. Koch, 1841) & 1 & 0 \\
\hline Trhypochthonius nigricans (Willmann, 1982) & 8 & 0 \\
\hline Nothrus silvestris Nicolet, 1855 & 11 & 2 \\
\hline Camisia spinifer (C.L. Koch, 1835) & 9 & 1 \\
\hline Heminothrus longisetosus (Willmann, 1925) & 2 & 0 \\
\hline Nanhermannia nana (Nicolet, 1855) & 8 & 0 \\
\hline Porobelba spinosa (Sellnick, 1920) & 8 & 0 \\
\hline Cepheus cepheiformis (Nicolet, 1855) & 8 & 0 \\
\hline Furcoribula furcillata (Nordenskiöld, 1901) & 1 & 0 \\
\hline Adoristes ovatus (C.L. Koch, 1839) & 11 & 0 \\
\hline Carabodes areolatus Berlese, 1916 & 1 & 0 \\
\hline Carabodes labyrinthicus (Michael, 1879) & 6 & 0 \\
\hline Carabodes marginatus (Michael, 1884) & 1 & 0 \\
\hline Carabodes subarcticus Trägardh, 1902 & 9 & 0 \\
\hline Tectocepheus velatus (Michael, 1880) & 160 & 39 \\
\hline Quadroppia quadricarinata (Michael, 1885) & 19 & 0 \\
\hline Microppia minus (Paoli, 1908) & 77 & 1 \\
\hline Oppiella nova (Oudemans, 1902) & 687 & 19 \\
\hline $\begin{array}{l}\text { Oppiella propinqua (Mahunka \& } \\
\text { Mahunka-Papp, 2000) }\end{array}$ & 30 & 0 \\
\hline Suctobelbella spp. Jacot, 1937 & 589 & 56 \\
\hline Conchogneta traegardhi (Forsslund, 1947) & 1 & 0 \\
\hline Eupelops torulosus (C.L. Koch, 1840) & 8 & 1 \\
\hline Parachipteria punctata (Nicolet, 1855) & 44 & 0 \\
\hline Galumna lanceata (Oudemans, 1900) & 3 & 0 \\
\hline Pergalumna nervosa (Berlese, 1914) & 5 & 2 \\
\hline Ceratozetes minimus Sellnick, 1928 & 3 & 0 \\
\hline Ceratozetes gracilis (Michael, 1884) & 1 & 0 \\
\hline Ceratozetes thienemanni Willmann, 1943 & 7 & 0 \\
\hline Chamobates borealis (Trägardh, 1902) & 10 & 1 \\
\hline Punctoribates punctum (C.L. Koch, 1839) & 1 & 0 \\
\hline Sheloribates initialis (Berlese, 1908) & 5 & 0 \\
\hline Scheloribates latipes (C.L. Koch, 1844) & 9 & 2 \\
\hline $\begin{array}{l}\text { Scheloribates circumcarinatus Weigmann \& } \\
\text { Miko, } 1998\end{array}$ & 1 & 0 \\
\hline Scheloribates spp. Berlese, 1908 & 1 & 0 \\
\hline
\end{tabular}

\section{DISCUSSION}

In most cases, soil acidity increases immediately after a forest fire (Bååth and Arnebrant, 1993; Certini, 2005; Cruz-Paredes et al., 2017; Hansen et al., 2017), but no significant difference of soil $\mathrm{pH}$ was observed in this study. Possibly, soil $\mathrm{pH}$ will increase when rain and melting snow drain ash into the soil. Changes in relative soil moisture and thickness of $\mathrm{O}$ horizon were also absent, as observed in previous studies (Lóšková et al., 2013; Saifutdinov et al., 2018; Auclerc et al., 2019). The insignificant differences between unburned and burned samples might be explained

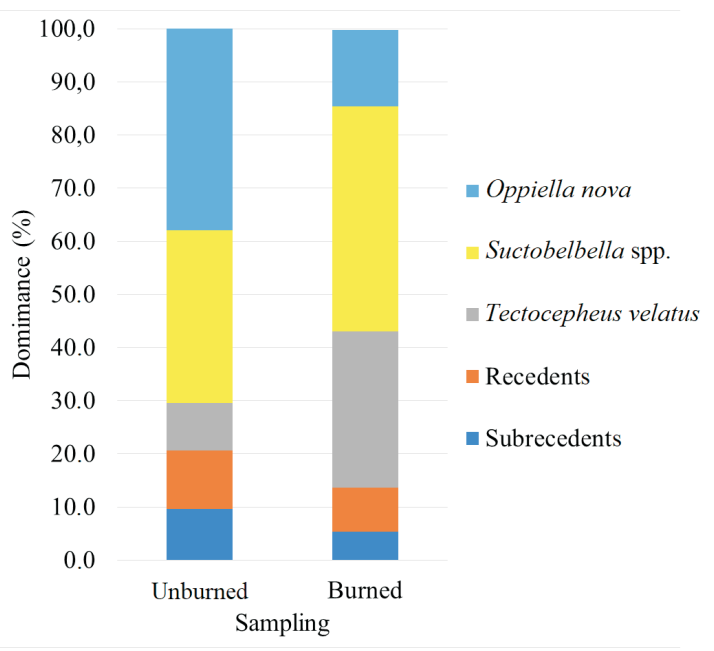

Fig. 5. Difference in dominance structure of Oribatida mites between unburned and burned soil samples.

by the thick moss cover that protected soil from direct fire damage by sustaining high soil moisture (Crossley et al., 1997; Migliorini et al., 2004; Gongalsky et al., 2012; Zaitsev et al., 2014). Previous studies have shown that during fire disturbance moss patches are refuges for soil fauna and serve as an important microhabitat for armoured mite community recovery (Crossley et al., 1997; Migliorini et al., 2004). The lack of overall vegetation cover might further increase soil heterogeneity and microclimate changes (Cerdà, 1999; Villegas et al., 2010). Furthermore, it results in the decrease of dead vegetation, which serves as an important food source for saprophagous species (Stefaniak and Seniczak, 1981; Schneider and Maraun, 2005; Perdomo et al., 2012). Our results on the increase in the organic carbon after the burn contrast with previously published findings (Certini, 2005; Bormann et al., 2008; Lóšková et al., 2013). Forest understorey and soil have been characterised as highly heterogeneous (Nielsen et al., 2010; Gongalsky et al., 2012; Wehner et al., 2016). The understorey directly influences burn severity, and heterogeneity of this factor can lead to a situation where deeply burned patches can be located close to the scorched ones where soil properties have been less influenced. These irregular changes on a plot-scale might have caused the increase in organic carbon, even if it has decreased at a forest-stand scale.

Fire had a negative effect on mite diversity and the number of individuals, as found in previous research (Kudryasheva and Laskova, 2002; Gongalsky et al., 2012; Kim and Jung, 2013). The only armoured mite taxa that did not suffer a decrease in numbers were Cosmochtonius lanatus and Brachychthonioidea spp (Table 2). Weak pigmentation and a relatively thin exoskeleton indicate that these taxa are euedaphic and inhabit deeper O horizon layers (Parisi et al., 2005). It is possible that soil buffering properties could have helped these taxa to survive the immediate effects of fire by minimising temperature changes during the fire (Scheinost et al., 1997; Zaitsev et al., 2014). As the total number of these primitive Oribatida in our study was low (seven C. lanatus individuals and two Brachychthonioidea), statistical 
analysis was not possible and it would be speculative to make reliable conclusions. Previous observations showed that Suctobelbella spp., O. nova and T. velatus are dominant taxa both before and after forest burns (Crossley et al., 1997). In our study, two of these taxa - Suctobelbella spp. and $O$. nova had a relatively high number of individuals before the burn, which should have provided their populations with a higher chance of survival (Crossley et al., 1997). Despite their large decrease in numbers after the immediate burn, they remained the most abundant oribatid mite after the disturbance (Fig. 5). Before the burn, the most abundant taxon was $O$. nova, but only a small number of individuals remained after the fire (Table 2). O. nova is less resistant to extreme soil temperature changes compared to Suctobelbella spp. (Malmström, 2008). A large number of individuals were also recorded the third taxa $-T$. velatus (Table 2). This armoured mite species was shown to have high temperature tolerance in laboratory studies and it has a well-developed exoskeleton (Malmström, 2008; Nakamura and Gotoh, 2009). Previous experiments suggest that a thick exoskeleton could be one of the factors increasing mite ability to survive forest fires (Walter and Proctor, 1999; Wikars and Schimmel, 2001; Malmström, 2008; Grabczyńska et al., 2009). Additionally, S. carinatus has a thick exoskeleton and has previously been shown to survive high temperatures (Malmström, 2008). However, in our study in the territory of Ādaži, the numbers of individuals of this species significantly decreased after the burn (Table 2). This might indicate that a high soil temperature was achieved during the soil, such that inhabiting deeper soil horizons was more beneficial for survival than a thick exoskeleton.

Soil invertebrates are adapted to relatively stable environmental conditions (Bengtsson, 2002; Nardi, 2007). In this study, the average values of soil factors did not change significantly, but the increased variability of these values indicated a significant change in the soil environment (Table 2). After the disturbance, distribution of oribatid mite communities was less associated with abiotic factors and vegetation, as in the new conditions they must survive in suboptimal conditions (Fig. 4). As for most soil arthropods, Oribatid mites have limited abilities to respond to rapid en- vironmental changes (Walter and Proctor, 1999; Capinera, 2006; Krantz and Walter, 2009). Changes in relative moisture, thickness of the $\mathrm{O}$ horizon and acidity of soil most likely did not directly contribute to the Oribatida mortality immediately after the burn, but only indicate changes in the environment. They might, however, affect the further succession process of Oribatida communities in the Scots pine forest, their population ability to recover and success in colonisation of new species (Hågvar, 1987; Henig-Sever et al., 2001). Moreover, acidophilic species, e.g., T. velatus and $N$. sylvestris could experience a further population decrease, caused by an increase in soil $\mathrm{pH}$ and amount of ash, that have been previously shown to have a negative effect (Hågvar and Amundsen, 1981; Hågvar, 1987).

Because in our study samples were not collected to represent all burn severity classes equally, the number of samples in each class differs (Fig. 6). The highest Shannon index was found for lightly burned samples — the class which was also represented by the highest number of samples. Despite these drawbacks, we observed a significant difference between the two severity classes: the lowest (scorched and light burn) and highest (medium and deep burn). Burn severity classes by Ryan (2002) that were used in this work are suitable for large-spatial-scale classification, for example, a forest-stand spatial scale. However, it is also possible that a different method of characterising the abiotic factors would have been more suitable for assessing fire severity at a sample-scale, e.g., ash layer thickness or ash pH (HenigSever et al., 2001). The relationships between fire severity, reduced number of individuals and diversity of oribatid mites have been studied previously (Wikars and Schimmel, 2001; Malmström, 2006; 2010; Kim and Jung, 2013), but results of this study can be interpreted in more detail, as most research does not consider Oribatid mites to the species level. Still, a few studies have been done on the immediate or long-term effects of forest fires in association with the responses of oribatid mite communities (Murvanidze et al., 2008; Kamczyc et al., 2017). Additional results on the responses of Oribatida mite to the fires at Ādaži will become available, as the data from the following three years after the burn are currently being processed. Thus, hope-

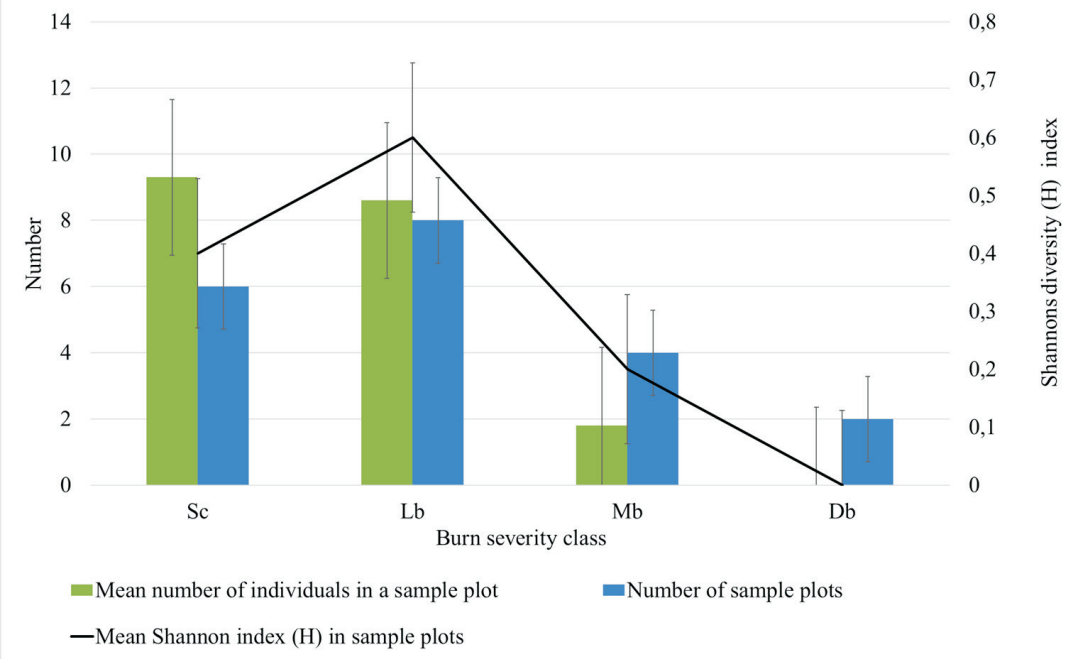

Fig. 6. The mean number of individuals of Oribatida mites (green) and the total number of sample plots (blue) on the background of the Shannon index $(H$, black line) among four different fire severity classes: Sc, scorched, Lb, lightly burned, Mb, moderately burned, $\mathrm{Db}$, deeply burned. 
fully, these results will provide more insight into post-fire succession mechanisms of oribatid mite communities and their dependence on various abiotic factors.

\section{ACKNOWLEDGEMENTS}

We wish to extend our thanks to Dr. biol. Voldemārs Spungis for his significant contribution to the study design. We are indebted to Dr. biol. Didzis Elferts (Faculty of Biology, University of Latvia) for consultations in data processing, Dr. chem. Linda Dobkēviča (Faculty of Geography and Earth Sciences, University of Latvia) for providing assistance on soil chemical analysis at the Soil Chemistry Laboratory. We thank B. biol. Ieva Mārdega for providing access to the protected landscape area "Ādaži" and her guidance on prescribed burning at the site. We also thank M. biol. Rüta Rozenfelde (Faculty of Biology, University of Latvia) for her valuable comments on previous versions of the manuscript. Last but not least, we thank B. biol. Rihards Mikelsons (Faculty of Biology, University of Latvia) for his assistance during sample collection.

\section{REFERENCES}

Anonymous (2005). International Organization of Standartization. Soil quality - Determination of $\mathrm{pH}$, ISO 10390:2005. International stage code: 90.93 (2010-01-05).

Anonymous (2019). RStudio: Integrated Development for R. RStudio Team. http://www.rstudio.com/ (accessed 10.10.2020).

Auclerc, A., Le Moine, J. M., Hatton, P. J., Bird, J. A., Nadelhoffer, J. (2019). Decadal post-fire succession of soil invertebrate communities is dependent on the soil surface properties in a northern temperate forest. Sci. Total Environ., 647, 1058-1068.

Bååth, E., Arnebrant, K. (1993). Microfungi in coniferous forest soil treated with lime or wood ash. Biol. Fertility Soils, 15, 91-95.

Barrios, E. (2007). Soil biota, ecosystem services and land productivity. Ecol. Econ., 64 (2), 269-285.

Bengtsson, J. (2002). Disturbance and resilience in soil animal communities. Eur. J. Soil Biol., 38, 119-125.

Bengtsson, J., Nilsson, G. S., Franc, A., Menozzi, P., (2000). Biodiversity, disturbances, ecosystem function and management of European forests. Forest Ecol. Manag., 132, 39-50.

Bormann, B., Homann, P. S., Darbyshire, R. L., Morrissete, B. A. (2008). Intense forest wildfire sharply reduces mineral soil $\mathrm{C}$ and $\mathrm{N}$ : The first direct evidence. Canad. J. Forest Res., 38 (11), 2771-2783.

Braun-Blanquet, J. (1964). Pflanzensoziologie, Grundzüge der Vegetationskunde. 3rd edition. Springer-Verlag, Berlin. 865 S. (in German).

Capinera, J. L. (2006). Encyclopaedia of Entomology. Vol. 2, F - O. Springer, Dordrecht. $1617 \mathrm{pp}$.

Cerdà, A. (1999). Parent material and vegetation affect soil erosion in Eastern Spain. Soil Sci. Soc. Amer. J., 63 (2), 362-368.

Certini, G. (2005). Effects of fire on properties of forest soils: A review. Oecologia, 143, 1-10.

Clarke, K. R., Warwick, R. M. (2001). Changes in Marine Communities: An Approach to Statistical Analysis and Interpretation. 2nd edition. Primer-E Ltd, Plymouth. 176 pp.

Crossley, D. A., Hansen, R. A. Jr., Lamoncha, K. L. (1997). Response of forest floor microarthropods to a forest regeneration burn at Wine Spring Watershed (southern Appalachians). In: Proceedings of the $1^{\text {st }}$ Biennial North American Forest Ecology Workshop, 24-27 June 1997, Raleigh, North Carolina. Institute of Ecology, University of Georgia, Raleigh, pp. 1-15.
Cruz-Paredes, C., Wallander, H., Kjøller, R., Rousk, J. (2017). Using community trait-distributions to assign microbial responses to $\mathrm{pH}$ changes and $\mathrm{Cd}$ in forest soils treated with wood ash. Soil Biol. Biochem., 112, 153-164.

Dhooria, M. S. (2016). Fundamentals of Applied Acarology. Springer Nature, Singapore. $470 \mathrm{pp}$.

Dindal, D. L. (1990). Soil Biology Guide. University of New Hapshive, Durham. $1980 \mathrm{pp}$.

Donis, J., Kitenberga, M., Snepsts, G., Matisons, R., Zarins, J., Jansons, A. (2017). The forest fire regime in Latvia during 1922-2014. Silva Fennica, 51 (5), DOI: 10.14214/sf.7746

Dunger, W., Fiedler, H. J. (1997). Methoden der Bodenbiologie. Gustav Fischer Verlag Jena, Villengang. $539 \mathrm{~S}$

Eisenbeis, G. (2006). Biology of Soil Invertebrates. In: Konig, H., Varma A (eds.). Intestinal Microorganisms of Termites and other Invertebrates. Springer-Verlag, Berlin, pp. 3-53.

Engelmann, H. D. (1978). Zur Dominanzklassifizierung von Bodenarthropoden. Pedobiologia, 18, 378-380.

Fowler, J., Cohen, L., Jarvis, P. (1998). Practical Statistics for Field Biology. Second Edition. John Wiley \& Sons Ltd., Chichester. 254 pp.

George, P. B. L., Keith, A. M., Creer, S., Barrett, G. L., Lebron, I., Emmet, B. A., Robinson, D. A., Jones, D. L. (2017). Evaluation of mesofauna communities as soil quality indicators in a national-level monitoring programme. Soil Biol. Biochem., 115, 537-546.

Gongalsky, K. B., Malmström, A., Zaitsev, A. S., Shakhab, S. V., Bengtsson, J., Persson, T. (2012). Do burned areas recover from inside? An experiment with soil fauna in a heterogeneous landscape. Appl. Soil Ecol., 59, 73-86.

Grabczyńska, O., Olejniczak, I., Prędecka, A., Russel, S. (2009). Short-term effects of prescribed forest fire on soil mites (Acari). Polish J. Ecol., 57 (4), 805-809.

Hågvar, S. (1987). Why do collemboles and mites react to changes in soil acidity? Entomologiske Meddelelser, 55, 115-119.

Hågvar, S., Amundsen, T. (1981). Effects of liming and artificial acid rain on the mite (Acari) fauna in coniferous forest. Oikos, 37 (1), 7-20.

Hammen, L. (1980). Glossary of Acarological Terminology. Dr. W. Junk Publishers, Hague. 284 pp.

Hansen, M., Bang-Andreasen, T., Sørensen, H., Ingerslev, M. (2017). Micro vertical changes in soil $\mathrm{pH}$ and base cations over time after application of wood ash on forest soil. Forest Ecol. Manag., 406, 274-280.

Henig-Sever, N., Poliakov, D., Broza, M. (2001). A novel method for estimation of wildfire intensity based on ash $\mathrm{pH}$ and soil microarthropod community. Pedobiologia, 45, 98-106.

Hutchins, M. W., Reynolds, B. C., Patch, S. P. (2011). Prescribed fire and the abundance of soil microarthropods in Northeast Georgia. Southeastern Naturalist, 10 (3), 489-500.

Johnstone, J. F., Chapin, F. S. (2006). Effects of soil burn severity on post-fire tree recruitment in boreal forest. Ecosystems, 9, 14-31.

Kagainis. U., Cera I., Juceviča E., Karpa A., Salmane I., Saulītis J., Spunğgis V., Telnov D., Melecis V., Jankevica L. (2020). The importance and potential value of a regional midsize arthropod collection: An example of IBULC. Int. J. Inclusive Museum, 13 (3), 45-77.

Kamczyc, J., Urbanowski, C., Pers-Kamczys, E. (2017). Mite communities (Acari: Mesostigmata) in young and mature coniferous forests after surface wildfire. Exper. Appl. Acarology, 72, 145-160.

Kim, J. W., Jung, C. (2008). Abundance of soil microarthropods associated with forest fire severity in Samcheok, Korea. J. Asia-Pacific Entomol., 11, 77-81.

Kim, J., Jung, C. (2013). Ecological resilience of soil oribatid mite communities after the fire disturbance. J. Ecol. Environ., 36 (2), 117-123.

Kirby, K. J., Watkins, C. (2015). Europe's Changing Woods and Forests: From Wildwood to Managed Landscapes. CABI publishing, Oxfordshire. $363 \mathrm{pp}$. 
Krantz, G. W., Walter, D. E. (2009). A Manual of Acarology. Third Edition. Texas Tech University Press, Texas. 807 pp.

Kruskal, J. B. (1964). Nonmetric multidimensional scaling: a numerical method. Psychometrika, 29, 115-129.

Kudryasheva, I. V., Laskova, L. M. (2002). Oribatid mites (Acariformes, Oribatei) as an index of postpyrogenous changes in podzol and peat soils of boreal forests. Biol. Bull., 29 (1), 92-99.

Larroulet, M. S., Hepper, E. N., Alvarez Redondo, M. P., Belmonte, V., Urioste, A. M. (2016). The Caldenal ecosystem: Effects of prescribed fire on soil chemical properties. Arid Land Res. Manag., 30 (1), 105-119.

Lepš, J., Šmilauer, P. (2003). Multivariate Analysis of Ecological Data Using CANOCO. Cambridge University Press, Cambridge. 284 pp.

Liiri, M., Haimi, J., Settälä, H. (2002). Community composition of soil microarthropods of acid forest soils as affected by wood ash application. Pedobiologia, 46, 108-124.

Lóšková, J., Luptáčik, P., Miklisová, D., Kováč, L. (2013). The effect of clear-cutting and wildfire on soil Oribatida (Acari) in windthrown stands of the High Tatra Mountains (Slovakia). Eur. J. Soil Biol., 55, 131-138.

Malmström, A. (2006). Effects of wildfire and prescribed burning on soil fauna in boreal coniferous forests. PhD dissertation, Swedish University of Agricultural Sciences, Uppsala, Sweden. 35 pp.

Malmström, A. (2008). Temperature tolerance in soil microarthropods: Simulation of forest-fire heating in the laboratory. Pedobiologia, 51, 419-426.

Malmström, A. (2010). The importance of measuring fire severity: Evidence from microarthropod studies. Forest Ecol. Manag., 260, 62-70.

McCune, B., Mefford, M. J. (1999). PC-ORD. Multivariate Analysis of Ecological Data. Version 4.0. MjM Software, Oregon. 237 pp.

Migliorini, M., Pigino, G., Avanzati, A. M., Salomone, N., Bernini, F. (2004). Experimental fires in a Mediterranean environment: Effects on Oribatid mite communities. Phytophaga, 14, 271-277.

Murvanidze, M., Arabuli, T., Kvavadze, E. R., Mumladze, L. (2008). The effect of fire disturbance on oribatid mite communities. In: Integrative Acarology. Proceedings of the 6th European Congress. 21-25 July, 2008, Montpellier. European Association of Acarologists, Montpellier, pp. 216-221.

Nakamura, Y. N., Gotoh, T. (2009). Comparative ultrastructural observation of the cuticle and muscle of an enchytraeid (Enchytraeus japonensis) and an oribatid species (Tectocepheus velatus) using transmission electron microscopy. J. Faculty Agricult. Kyushu Univ., 54 (1), 97-101.

Nardi, J. B. (2007). Life in the Soil. The University of Chicago Press, Chicago. 293 pp.

Nielsen, U. N., Osler, G. H. R., Campbell, C. D., Neilson, R., Burslem, D. F. R. P., van der Wal, R. (2010). The enigma of soil animal species diversity revisited: The role of small-scale heterogeneity. PloS ONE, 5 (7), e11567.

Olejniczak, I., Górska, E. B., Prędecka, A., Hewelke, E., Gozdowski, D., Korc, M., Panek, E., Tyburski, L., Skawińska, M., Oktaba, M., Boniecki,, P., Kondras M., Oktaba, L. (2019). Selected biological properties of the soil in a burnt-out area under old pine trees three years after a fire. Middle Pomeranian Scientific Society of the Environment Protection, 21, 1279-1293.

Parisi, V., Menta, C., Gardi, C., Jacomini, C., Mozzanica, E. (2005). Microarthropod communities as a tool to assess soil quality and biodiversity: A new approach in Italy. Agricult. Ecosyst. Environ., 105, 323-333.

Parsons, A., Robichaud, P. R., Lewis, S. A., Napper, C., Clark, J. T. (2010). Field Guide for Mapping Post-Fre Soil Burn Severity. United States Department of Agriculture, Rocky Mountains Reasearch Station. 49 pp.
Parviainen, J. (1996). The impact of fire on Finnish forests in the past and today. Silva Fennica, 30 (2-3), 353-359.

Pastro L. A., Dickman, C. R., Letnic, M. (2011). Burning for biodiversity or burning biodiversity? Prescribed burn vs. wildfire impacts on plants, lizards, and mammals. Ecol. Appl., 21 (8), 3238-3253.

Perdomo, G., Evans A., Maraun, M., Sunnucks, P., Thompson, R. (2012). Mouthpart morphology and trophic position of microarthropods from soils and mosses are strongly correlated. Soil Biol. Biochem., 53, 56-63.

Rove, I. (Ed.) (2008). Nature Management Plan for Protected Landscape Area "Ādaži” [Aizsargājamo ainavu apvidus "Ādaži" dabas aizsardzības plāns]. Latvijas Dabas fonds, Rīga. 122 lpp. (in Latvian).

Ryan, K. C. (2002). Dynamic interactions between forest structure and fire behavious in boreal ecosystems. Silva Fennica, 36 (1), 13-39.

Saifutdinov, R. A., Gongalsky, K. B., Zaitsev, A. S. (2018). Evidence of a trait-specific response to burning in springtails (Hexapoda: Collembola) in the boreal forests of European Russia. Geoderma, 332, 173-179.

Scheinost, A. C., Sinowski, W., Auerswald, K. (1997). Regionalization of soil buffering functions: A new concept applied to K/Ca exchange curves. Adv. GeoEcol., 30, 23-38.

Schimmel, J., Granström, A. (1996). Fire severity and vegetation response in the boreal Swedish forest. Ecology, 77 (5), 1436-1450.

Schneider, K., Maraun, M. (2005). Feeding preferences among dark pigmented fungi ("Damatiacea") indicate trophic niche differentiation of oribatid mites. Pedobiologia, 49, 61-67.

Southwood, T. R. E., Henderson, P. A. (2000). Ecological Methods. Third edition. Blackwell Science Ltd., London. 575 pp.

Stamou, G. P., Asikidis, M. D., Argyropoulou, M. D., Sgardelis, S. P. (1993). Ecological time versus standard clock time: The asymmetry of phenologies and the life history strategies of some soil arthropods from Mediterranean ecosystems. Oikos, 66 (1), 27-35.

Stefaniak, O., Seniczak, S. (1981). The effect of fungal diet on the development of Oppia nitens (Acari, Oribatei) and on the microflora of its alimentary tract. Pedobiologia, 21, 202-210.

Tyurin, I. V. (1951). Analytical procedure for a comparative study of soil humus. Scientific Works of V.V. Dokuchaev Soil Science Institute [Тюрин, И. В. К методике анализа для сравнительного изучения состава почвенного перегноя или гумуса. Тр. Почв, ин-та им В.В. Докучаева], 33a, 5-21.

Villegas, J. C., Breshears, D. D., Zou, C. B., Law, D. J. (2010). Ecohydrological controls of soil evaporation in deciduous drylands: How the hierarchical effects of litter, patch and vegetation mosaic cover interact with phenology and season. J. Arid Environ., 74 (5), 595-602.

Walter, D. E., Proctor, H. C. (1999). Mites: Ecology, Evolution \& Behavior. CABI publishing, New York. 322 pp.

Wehner, K., Norton, R. A., Blüthgen, N., Heethoff, M.. (2016). Specialization of oribatid mites to forest microhabitats - the enigmatic role of litter. Ecosphere, 7 (3), e01336.

Weigmann, G. (2006). Hornmilben (Oribatida). Die Tierwelt Deutshclands, Bd. 76. Goecke \& Evers, Keltern. 520 S. (in German).

Wikars, L. O., Schimmel, J., (2001). Immediate effects of fire-severity on soil invertebrates in cut and uncut pine forests. Forest Ecol. Manag., 141, 189-200.

Zaitsev, A. S., Gongalsky, K. B., Malmström, A., Persson, T., Bengtsson, J. (2016). Why are forest fires generally neglected in soil fauna research? A mini-review. Appl. Soil Ecol., 98, 261-271.

Zaitsev, A. S., Gongalsky, K. B., Persson, T., Bengtsson, J. (2014). Connectivity of litter islands remaining after a fire and unburnt forest determines the recovery of soil fauna. Appl. Soil Ecol., 83, 101-108.

Zaitsev A. S., van Straalen, N. M. (2001). Species diversity and metal accumulation in oribatid mites (Acari, Oribatida) of forests affected by a metallurgical plant. Pedobiologia, 45, 467-479.

Received 16 December 2020

Accepted in the final form 12 March 2021 

(PINUS SYLVESTRIS) MĒTRĀJĀ LATVIJĀ

Kontrolēta dedzināšana tiek izmantota, lai uzturētu un atjaunotu biotopus, kā arī aizsargātu un paaugstinātu bioloğisko daudzveidību. Zināšanas par augsnes faunu ir ierobežotas, it īpaši par tās sabiedrību atbildes reakcijām uz degšanu. Pētījuma mērḳis bija noskaidrot kontrolētas dedzināšanas tūlītējo ietekmi uz augsnes bruṇērču (Acari: Oribatida) sabiedrībām, veğetācijas segumu un augsnes fiziokīmiskajām īpašībām boreālā skujkoku mežā Latvijā. Augsnes paraugi tika ievākti aizsargājamo ainavu apvidū "Ādaži”" tieši pirms kontrolētas dedzināšanas un 16 dienas vēlāk. Abiotiskajiem faktoriem netika konstatētas būtiskas izmaiņas. Degšana būtiski samazināja veǵetācijas segumu. Pēc degšanas kopējais reǵistrētais bruṇērču indivīdu skaits samazinājās par 93\%, bet sugu kopskaits — par $77 \%$. Izmaiņas bruṇērču sabiedrībās būtiski ietekmēja degšanas ietekmes smagums. Indivīdu skaita samazinājums tika reǵistrēts visiem taksoniem, izṇemot Brachychthonioidea spp. un Cosmochthonius lanathus. Būtisks samazinājums tika konstatēts sugām, kuras nedegušajos paraugos uzrādīja augstu dominanci - Suctobelbella spp., Oppiella nova un Tectocepheus velatus. Pēc degšanas Suctobelbella spp. bija eudominanta gints, bet Tectocepheus spp. — dominanta. 